\title{
The genus Aurinia Desv. (Brassicaceae) in ZA and ZAHO herbaria
}

\author{
IVANA REŠETNIK ${ }^{1 *}$, IVA BETEVIĆ DADIĆ ${ }^{2}$, MARINA BABIĆ ${ }^{1}$ \\ ${ }^{1}$ Department of Biology, Faculty of Science, University of Zagreb, Marulićev trg 20/II, HR-10000 \\ Zagreb, Croatia \\ ${ }^{2}$ Bitoljska 8, HR-10090 Zagreb, Croatia
}

*Autor za dopisivanje / corresponding author: ivana.resetnik@biol.pmf.hr

Tip članka / article type: kratko znanstveno priopćenje / short scientific communication Povijest članka / article history: primljeno / received: 19.9.2019., prihvaćeno / accepted: 27.11.2019. URL: https://doi.org/10.46232/glashbod.8.1.1

\section{Rešetnik, I., Betević Dadić, I., Babić, M. (2020): The genus Aurinia Desv. (Brassicaceae) in ZA} and ZAHO herbaria. Glas. Hrvat. bot. druš. 8(1): 1-7.

\section{Abstract}

This paper presents the collection of the genus Aurinia Desv. species in ZA and ZAHO herbaria. The revision and the analyses of the material are presented. Herbarium specimens from these two herbaria were digitized and the data from the original herbarium labels were inserted in the Flora Croatica Database. A total of 203 herbarium sheets were digitized and nine taxa (A. corymbosa Griesb., A. leucadea (Guss.) K. Koch ssp. leucadea, A. leucadea (Guss.) K. Koch ssp. media (Host) Plazibat, A. petraea (Ard.) Schur, A. petraea (Ard.) Schur ssp. microcarpa (Vis.) Plazibat, A. saxatilis (L.) Desv., A. saxatilis (L.) Desv. ssp. orientalis (Ard.) T. R. Dudley, A. saxatilis (L.) Desv. ssp. saxatilis, A. sinuata (L.) Griseb.) were registered within studied collections. The specimens originate from 16 European countries and the majority of herbarium sheets were collected in Croatia. The majority of specimens were collected between 1900s and 1950s. The comparison between the recorded distribution data in the Flora Croatica Database and the distribution based on herbarium specimens is made and the herbarium specimens generally well represent the distribution range of studied taxa.

Keywords: Aurinia, herbarium specimens, ZA, ZAHO

Rešetnik, I., Betević Dadić, I., Babić, M. (2020): Rod Aurinia Desv. (Brassicaceae) u ZA i ZAHO zbirkama. Glas. Hrvat. bot. druš. 8(1): 1-7.

\section{Sažetak}

U radu je prikazana zastupljenost vrsta roda Aurinia Desv. u sklopu herbarijskih zbirki ZA i ZAHO. Napravljena je revizija i analiza svih herbarijskih primjeraka. Herbarijski primjerci su digitalizirani, a podaci s originalnih herbarijskih etiketa su uneseni u bazu podataka Flora Croatica. Digitalizirano je ukupno 203 herbarijskih listova i zabilježeno je devet svojti (A. corymbosa Griesb., A. leucadea (Guss.) K. Koch ssp. leucadea, A. leucadea (Guss.) K. Koch ssp. media (Host) Plazibat, A. petraea (Ard.) Schur, 
A. petraea (Ard.) Schur ssp. microcarpa (Vis.) Plazibat, A. saxatilis (L.) Desv., A. saxatilis (L.) Desv. ssp. orientalis (Ard.) T. R. Dudley, A. saxatilis (L.) Desv. ssp. saxatilis, A. sinuata (L.) Griseb.). Primjerci potječu iz 16 europskih zemalja, te je većina primjeraka sakupljena na području Republike Hrvatske. Većina herbarijskih primjeraka je sakupljena između 1900-1950 godine. Učinjena je usporedba podataka o rasprostranjenosti tih vrsta u Flora Croatica bazi podataka s onima o njihovoj rasprostranjenosti prema herbarijskim primjercima, te se distribucija herbarijskih primjeraka uglavnom dobro poklapa sa stvarnom rasprostranjenosti istraživanih svojti.

Ključne riječi: Aurinia, herbarijski primjerci, ZA, ZAHO

\section{Introduction}

Aurinia Desv. is a genus belonging to the tribe Alysseae DC. (Brassicaceae), which has the centre of origin and diversity in south-eastern Europe. The circumscription of the genus was recently revised and now the monophyletic Aurinia comprises four species endemic to Balkan Peninsula (A. corymbosa Griseb., A. gionae (Quézel \& Contandr.) Greuter \& Burde, A. moreana Tzanoud. \& Iatroú and $A$. petraea (Ard.) Schur), two species spanning Balkan and Apennine Peninsulas (A. leucadea (Guss.) K.Koch and $A$. sinuata (L.) Griseb.) and one species being more widespread, extending its range from the Balkan Peninsula to central Europe and Asia Minor (A. saxatilis (L.) Desv.) (Rešetnik et al. 2013, Španiel et al. 2015). Morphologically, the species within the genus are perennial herbs with erect to ascending stems and with an indumentum of short-stalked to subsessile 7-12-rayed trichomes. Basal leaves are entire, repand, dentate, sinuate, or rarely pinnately lobed, while cauline leaves are

Table 1. The number of herbarium sheets for each taxon across the studied ZA and ZAHO herbaria. The taxa native in Croatia are bolded.

\begin{tabular}{lcccc} 
Taxon name & ZA & ZAHO & total \\
Aurinia corymbosa Griesb. & 12 & 18 & 30 \\
Aurinia leucadea (Guss.) K. Koch ssp. leucadea & 15 & 2 & 17 \\
Aurinia leucadea (Guss.) K. Koch ssp. media (Host) Plazibat & 16 & 2 & 18 \\
Aurinia petraea (Ard.) Schur & 3 & 0 & 3 \\
Aurinia petraea (Ard.) Schur ssp. microcarpa (Vis.) Plazibat & 5 & 1 & 6 \\
Aurinia saxatilis (L.) Desv. & 1 & 0 & 1 \\
Aurinia saxatilis (L.) Desv. Ssp. orientalis (Ard.) T. R. Dudley & 10 & 7 & 17 \\
Aurinia saxatilis (L.) Desv. ssp. saxatilis & 31 & 1 & 32 \\
Aurinia sinuata (L.) Griseb. & 77 & 2 & 79 \\
\hline Total & $\mathbf{1 7 0}$ & $\mathbf{3 3}$ & $\mathbf{2 0 3}$
\end{tabular}


considerably smaller than basal leaves, entire, dentate, or sinuate. Racemes are many flowered, exclusively yellow-flowered and elongated in fruit. There are 4-8(-16) ovules per ovary. Fruits (silicles) are dehiscent, inflated or not, obovate, obovoid, ovate, orbicular, or globose, terete or strongly latiseptate, with papery valves. Seeds are winged all around, ovate to orbicular, and strongly flattened (Španiel et al 2015).

Recent phylogenetic studies of the tribe Alysseae revealed that the relationships among and delimitation of extant Aurinia species are not resolved and are hampered by incongruences between nuclear and plastid DNA data, probably as a result of hybridisation or incomplete lineage sorting (Rešetnik et al. 2013). Therefore further research focusing on phylogeny of the genus, delimitation of species boundaries, diversification of all species and their individual phylogeographic histories is in progress. As a part of this studies, a revision and the analyses of the herbarium specimens in ZA and ZAHO herbaria were done. Specifically, the aim of this paper is to: 1) determine the number, origin and the age of herbarium sheets, and 2) provide comparison between their recorded natural distributions in Croatia and the distribution data based on herbarium specimens.

\section{Materials and methods}

In 2018, a detailed study of all genus Aurinia species was made in the herbarium collections ZA and ZAHO (acronyms are according to Thiers 2019). During this process, all herbarium specimens were mounted onto new herbarium sheets and the original metadata from all herbarium labels were included in the Flora Croatica Database (FCD) as described in Šegota et al. (2017). Furthermore, localities in Croatia were georeferenced by using the GeoRef application (Croatian Agency for Environment and Nature 2018) and finally all specimens were scanned with inversed Epson Expression 11000XL Pro A3 scanner and imported in FCD (Nikolić 2018). The systemized and digitalized specimens are freely available through the FCD portal (https://hirc.botanic.hr/fcd) and on the Herbarium ZA and ZAHO web site (http:// herbariumcroaticum.biol.pmf.hr/).

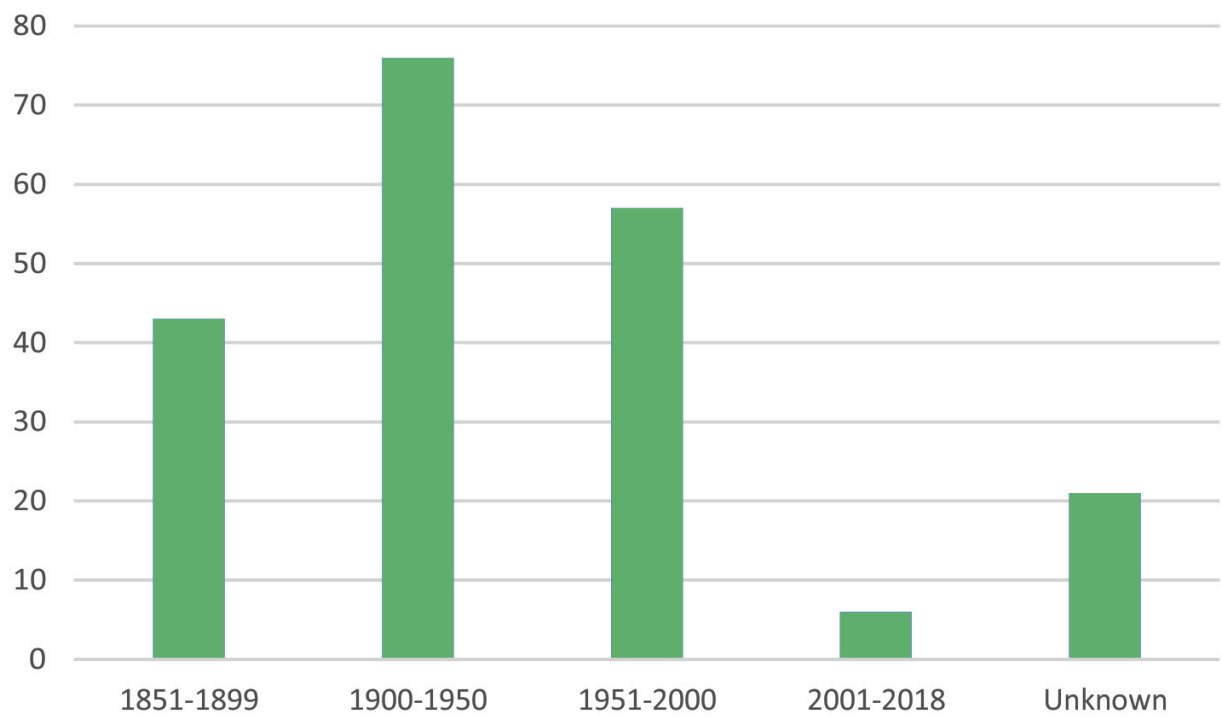

Figure 1. Temporal distribution of herbarium sheets of the genus Aurinia Desv. from ZA and ZAHO based on collection periods. 


\section{Results and discussion}

In total, 203 herbarium sheets were found within the two herbaria, with 170 sheets stored in ZA and 33 sheets stored in ZAHO (Table 1). The highest number of sheets, 79 in total, belonged to $A$. sinuata, 77 and 2 in ZA and ZAHO, respectively (Table 1). The herbarium specimens originate from 16 European countries and the majority of herbarium sheets were collected in Croatia (120 sheets i.e. 59.1\%), followed by Macedonia (26 sheets) and Montenegro (11 sheets), while from the other countries, one to eight sheets were collected. According to the location data on the herbarium labels it was possible to georeference $92 \%$ of herbarium sheets. The most productive collector of the studied herbarium material was Ivo Horvat (30 herbarium sheets), who is the major collector of the ZAHO collection. Miško Plazibat stored 24 herbarium sheets, Stjepan Horvatić 23, Ljudevit Rossi and Ambroz Haračić stored 13 sheet each, Karlo Bošnjak 12 sheets, while other 50 collectors contributed with less than seven herbarium sheets

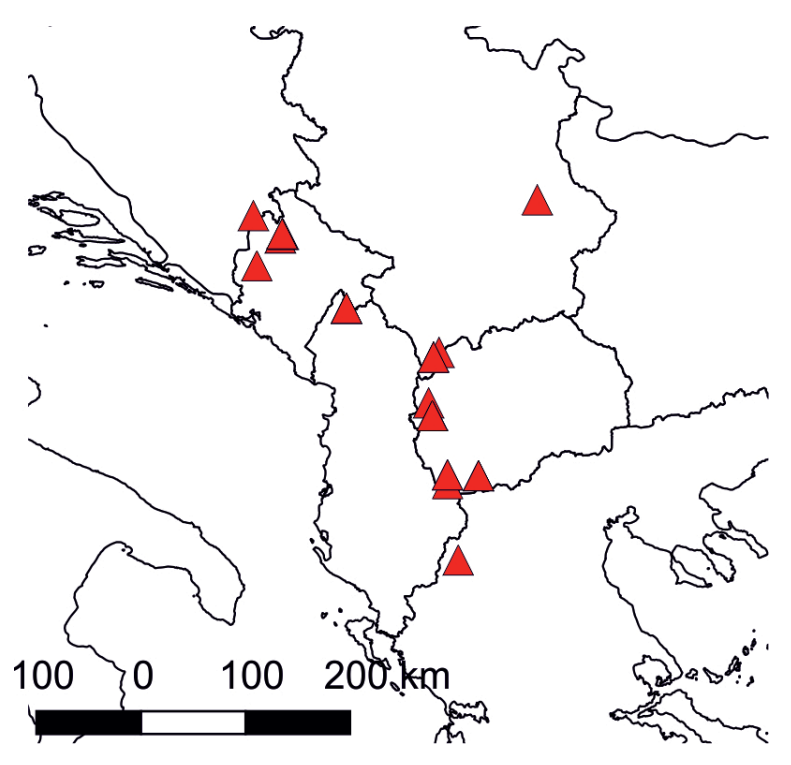

Figure 2. Distribution map of Aurinia corymbosa Griseb. based on Flora Croatica Database and herbarium sheets from ZA and ZAHO herbaria. Red triangles represent the localities from herbarium sheets of ZA and ZAHO.

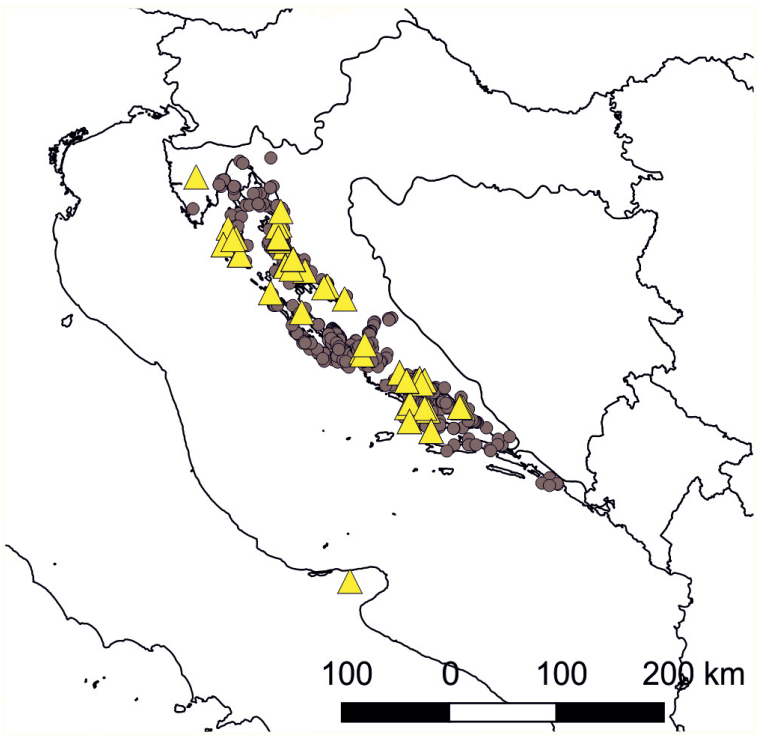

Figure 3. Distribution map of Aurinia sinuata (L.) Griseb. based on Flora Croatica Database and herbarium sheets from ZA and ZAHO herbaria. Yellow triangles represent the localities from herbarium sheets of ZA and ZAHO, brown dots represent the literature, field and other observation data stored in FCD.

each. In terms of collecting period, the majority of specimens were collected between 1900s and 1950s (Fig. 1), what is in line with the thus far analysed material from ZA and ZAHO (Šegota et al. 2017, Rešetnik et al. 2019, Terlević and Rešetnik 2020). A number of specimens was collected also in the period between 1951 and 2000, mainly in the 1990s, due to the research of the tribe Alysseae conducted by Miško Plazibat, the curator of ZA and ZAHO herbaria at that time. The oldest specimen is Aurinia saxatilis (L.) Desv. subsp. saxatilis, collected in 1851 by anonymous collector in the vicinity of Muggendorf in Germany, while 21 herbarium sheets lack data on collecting period.

Out of the seven species currently attributed within the genus, the herbarium specimens of two Greek endemic species, $A$. gionae and $A$. moreana, are not present in ZA and ZAHO. The species A. corymbosa which is not naturally occurring in Croatia, is represented with 30 herbarium sheets (Table 1), mostly from ZAHO and from localities in Macedonia 
and Montenegro, although it is also distributed throughout Albania and mainland Greece (Fig. 2). All other four species are included in Index Florae Croaticae (Nikolić 1996). The most frequent of them is A. sinuata which is distributed along the eastern Adriatic coast and islands, and also less frequently occurring on few localities on the Apennine Peninsula (Gargano, Abruzzo; Brullo and Guarino 2017). The herbarium specimens well represent the whole distribution range, although the specimens from the most southern localities in the Dubrovnik region are lacking in ZA and ZAHO (Fig. 3). Only one sheet from the Apennine Peninsula (Gargano: Cagnano monte dell Arezzo, ZA-49432) is present in ZA. The second most frequent species is another amphi-Adriatic species, A. leucadea, although less abundant due to its more specific chasmophytic habitat requirements. Specimens from the distribution edges, i.e. the north-western and the south-eastern localities, and from the Apennine Peninsula are missing in our collections (Fig. 4).

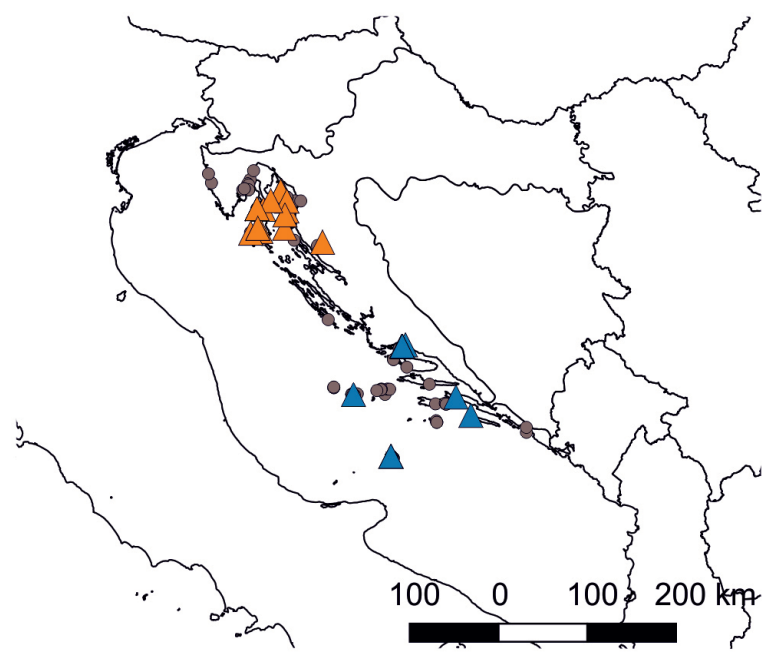

Figure 4. Distribution map of Aurinia leucadea (Guss.) K.Koch based on Flora Croatica Database and herbarium sheets from ZA and ZAHO herbaria. Orange triangles represent the localities of subspecies media (Host) Plazibat and blue triangles represent the localities of $A$. leucadea subsp. leucadea from herbarium sheets of ZA and ZAHO, brown dots represent the literature, field and other observation data stored in FCD.

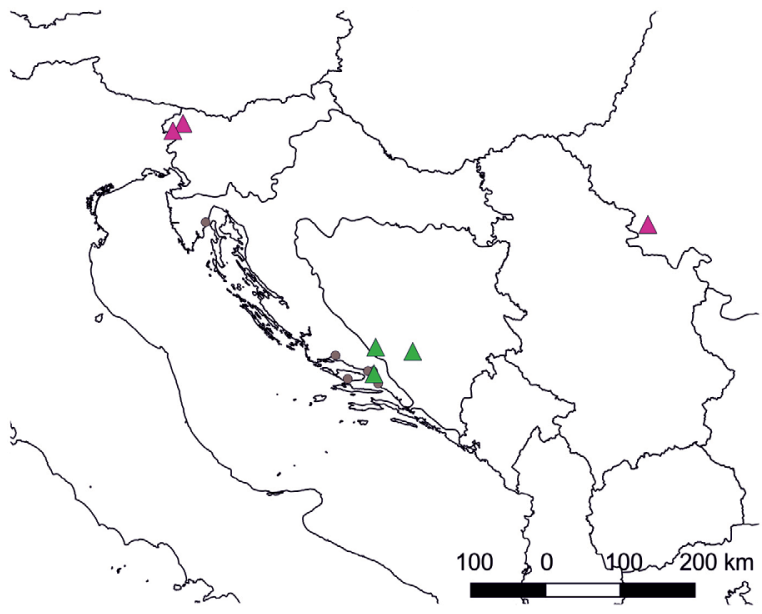

Figure 5. Distribution map of Aurinia petraea (Ard.) Schur based on Flora Croatica Database and herbarium sheets from ZA and ZAHO herbaria. Magenta triangles represent the localities of $A$. petrae $a$ and green triangles represent the localities of A. petraea subsp. microcarpa (Vis.) Plazibat from herbarium sheets of ZA and ZAHO, brown dots represent the literature, field and other observation data stored in FCD.

Aurinia leucadea is taxonomically divided into nominal subspecies A. leucadea subsp. leucadea, A. leucadea subsp. media (Host) Plazibat and A. leucadea subsp. scopulorum (Ginzb.) Plazibat. The last one is distributed on the most remote islands Jabuka and Kamik (Plazibat 2006) and thus far it is not represented with herbarium specimens in ZA and ZAHO. The species $A$. petraea has an interesting disjunct distribution with three main areas: the eastern area which includes localities from western Romanian and eastern Serbia, the central area including localities from Biokovo in Croatia and central to south-eastern part of Bosnia and Herzegovina, and the western area with the localities from western Slovenia and neighbouring part of north-eastern Italy. The plants occurring in the central area have traditionally been regarded as $A$. petraea subsp. microcarpa (Vis.) Plazibat, although firstly described on a species level as Vesicaria microcarpa Vis. (Visiani 1829). Currently only this taxon is regarded as present in Croatian flora. Due to the morphological similarities there has always been a continuous 
phylogenetic and taxonomical confusion between A. petraea and A. corymbosa, including also the taxon A. microcarpa and their relationships have not yet been resolved with molecular markers (Rešetnik et al. 2013). In ZA and ZAHO herbaria a few specimens from all three areas of distribution are present (Fig. 5). The literature data indicating the presence of A. petraea on localities in Istria, Split and Brač are not confirmed with herbarium specimens and are most probably based on erroneous identifications. The species with the widest distribution in the genus is A. saxatilis. It is distributed from south-eastern Germany, through central Europe, eastern and southern Balkan Peninsula, into Asia Minor. Due to its polymorphic nature it has been taxonomically divided into three subspecies, i.e. A. saxatilis subsp. saxatilis, A. saxatilis subsp.

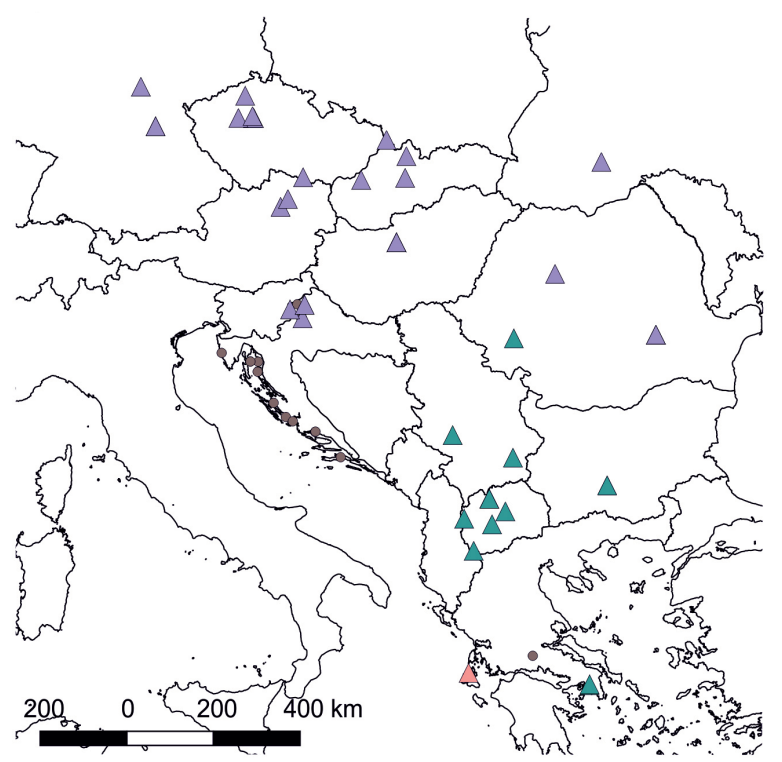

Figure 6. Distribution map of Aurinia saxatilis (L.) Desv. based on Flora Croatica Database and herbarium sheets from ZA and ZAHO herbaria. Violet triangles represent the localities of $A$. saxatilis subsp. saxatilis, turquoise triangles represent the localities of A. saxatilis subsp. orientalis (Ard.) T.R. Dudley and tan triangles represent the localities of A. saxatilis subsp. megalocarpa (Hausskn.) T.R. Dudley from herbarium sheets of ZA and ZAHO, brown dots represent the literature, field and other observation data stored in FCD. orientalis (Ard.) T.R.Dudley and A. saxatilis subsp. megalocarpa (Hausskn.) T.R.Dudley which are also to some extent geographically separated (Persson 1971). According to the FCD data and Index Florae Croaticae (Nikolic 1996), the species is present in Croatia, however its occurrence should be regarded as highly doubtful. The only herbarium specimens supporting its occurrence in Croatia are two Schlosser sheets from "In saxosis montium Ivanščica et alibi” and one Schlosser sheet designated "In montanis rupibusque calcareus Croatiae australis" without the collection date (ZA-27962, ZA-27963, ZA-27964). The specimen ZA-27962 is in poor condition, completely lacking basal leaves and with flowers in early flowering stage, thus not enabling reliable identification. On the herbarium sheet ZA-27963 there are several specimens that represent a mixture of two taxa, $A$. saxatilis and $A$. leucadea, thus representing a suspicious gathering. Only the specimen ZA-27964 could be regarded as a trustworthy material. The other two herbarium sheets stored in ZA are from cultivated material grown in gardens in continental part of Croatia, which is not surprising as $A$. saxatilis is often sold and planted as an ornamental species. There is also one herbarium sheet from Ex herb. Vukotinović, with material collected by Tommasini originally labelled "Alyssum [Aurinia] leucadeum Guss., Ex insula Dalmatiae Pelagosa" (ZA-9189) with three separated branches, among which two of them were identified by M. Plazibat as A. saxatilis subsp. orientalis (Plazibat 2006, 2009). However, since the material is incomplete and in early flowering stage its identification is questionable, since the most reliable characters in Aurinia identification include the fruit and seed characteristics and basal leaves. All the literature and observation data along the Adriatic coast in FCD are most probably erroneous identifications of other autochthonous Aurinia taxa i.e. A. sinuata and A. leucadea, as already postulated by Persson (1971). Therefore, until the occurrence of $A$. saxatilis, both in north-western continental Croatia and along the coast, is confirmed and demonstrated with reliable herbarium specimens, the species should be excluded from the Croatian flora. 
The data presented here is the starting point for the ongoing detailed study on the phylogeny, phylogeography and taxonomy of the genus Aurinia which is currently in progress. Extensive herbarium material throughout the distribution range is being collected within the current study and it will be incorporated in ZA collection, thus providing more recent material. The preliminary results obtained thus far indicate that some taxonomical and nomenclature changes will most probably be needed, therefore an update to the current data in FCD and Index Florae Croaticae can be expected in the near future.

\section{Acknowledgements}

This work was supported by Unity Through Knowledge Fund under the project „Nextgeneration systematics of the south-eastern European genus Aurinia (Brassicaceae): evolution and phylogeography of an intricate plant group".

\section{References}

Brullo, S., Guarino, R. (2017): Aurinia. In: Pignatti, S. (eds.): Flora d'Italia [2nd edition]. Volume 2., Edagricole, Bologna, 961-964.

Croatian Agency for Environment and Nature (2018): Informacijski sustav zaštite prirode, Georef - Aplikacija za georeferenciranje. http:// georef.iszp.hr/ (accessed January - June 2018).

Nikolić, T. (ed.) (1996): Flora Croatica, Index florae Croaticae Pars 2. Nat. Croat. 6, Suppl. 1: 1-232.

Nikolić, T. (ed.) (2018): Flora Croatica Database. University of Zagreb, Faculty of Science, Department of Botany and Botanical Garden, Zagreb. http:// hirc.botanic.hr/fcd/ (accessed December 5, 2018).

Persson, J. (1971): Studies in the Aegean Flora XIX. Notes on Alyssum and some other genera of Cruciferae. Botaniska notiser 124: 399-418.
Plazibat, M. (2006): Biosistematska i fitokemijska istraživanja nekih svojti tribusa Alysseae (Brassicaceae). Doktorska disertacija. Prirodoslovno-matematički fakultet, Sveučilište u Zagrebu. Plazibat, M. (2009): A short synopsis of the tribe Alysseae (Brassicaceae) in Croatia with some taxonomic novelties. Natura Croatica 18: 401-426.

Rešetnik, I., Satovic, Z., Schneeweiss, G.M., Liber, Z. (2013): Phylogenetic relationships in Brassicaceae tribe Alysseae inferred from nuclear ribosomal and chloroplast DNA sequence data. Molecular Phylogenetics and Evolution 69: 772-785.

Rešetnik, I., Bešenić, M., Dujmović, L., Rubinić, M., Vrbanec, Z. (2019): To collect or not to collect? The ZA and ZAHO herbarium specimens of some frequent species. Glasnik Hrvatskog botaničkog društva 7(2): pages.

Šegota, V., Buzjak, S., Vilović, T., Sedlar, Z., Rešetnik, I., Bogdanović, S. (2017): Curators in action: intricate genus Fritillaria L. (Liliaceae). Glasnik Hrvatskog botaničkog društva 50(2): 4-14.

Španiel, S., Kempa, M., Salmerón-Sánchez, E., Fuertes-Aguilar, J., Mota, J.F., Al-Shehbaz, I.A., German, D.A., Olšavská, K., Šingliarová, B., Zozomová-Lihová, J., Marhold, K. (2015): AlyBase: database of names, chromosome numbers, and ploidy levels of Alysseae (Brassicaceae), with a new generic concept of the tribe. Plant Systematics and Evolution 301: 2463-2491.

Terlević, A., Rešetnik, I. (2020): Inventory of the historical Dianthus sylvestris herbarium materials from Herbarium Croaticum and Herbarium Ivo and Marija Horvat. Glasnik Hrvatskog botaničkog društva 8(1): 8-14

Thiers, B. (2017): Index Herbariorum. A global directory of public herbaria and associated staff. New York Botanical Garden's Virtual Herbarium. http:// sweetgum.nybg.org/ih/ (accessed December 2018). Visiani, R. (1829): Plantae rariores in Dalmatia recens detectae a Roberto de Visiani. Flora (Regensb.) 12, Ergänzungsblätter zur Flora 1: 18. 